\title{
Migration Trend Analysis of Farmers and Agricultural Labours in Yadgir District of Karnataka, India
}

\author{
Moulasab*, D.M. Chandargi and D.G. Sathihal \\ University of Agricultural Sciences, Raichur - 584 104, Karnataka, India \\ *Corresponding author
}

\begin{tabular}{|l|}
\hline Ke y w o r d s \\
$\begin{array}{l}\text { Inter District, Intra } \\
\text { district, Migration, } \\
\text { Seasonal and } \\
\text { Temporary } \\
\text { migration }\end{array}$ \\
\hline Article Info \\
\hline $\begin{array}{l}\text { Accepted: } \\
\text { 26 December } 2017 \\
\text { Available Online: } \\
\text { 10 January } 2018\end{array}$ \\
\hline
\end{tabular}

A B S T R A C T

The present study was conducted to know the migration trend of farmers and agricultural labors in Yadgir district of north Karnataka during the year 2014-15. With the help of Karnataka state department of Agriculture and also KALIKA NGO 15 villages were selected from the district and from each village 10 farmers and 10 agricultural labors were selected using simple random sampling thus making a total sample of 300 respondents. The data was collected personally from the respondents using structured and standardized interview schedule developed for the study. The data collected was tabulated and analyzed using appropriate statistical tools. The results of the study revealed that, less than half $(40.00 \%)$ of the respondents were middle aged and half $(50.00 \%)$ of them were illiterates. With regard to land holding, equal per cent $(28.33 \%)$ of them were having a land holding of 1.1-2acre and 2.1-3 acres, majority $(46.00 \%)$ of the them belonged to medium farming experience category. Majority $(73.67 \%)$ of the respondents was having family size of more than 4 members and majority $(69.33 \%)$ of the respondents was male and belonged to medium income group. More than half $(66.00 \%)$ of the respondents were inter-district migrants falling under rural to urban migration and majority $(73.00 \%)$ of them was seasonal migrants. Large majority $(97.67 \%)$ of the respondents migrated due to poor economic condition of the family. Large majority $(96.67 \%$ ) of the respondents' purpose of migration was to get regular income.

\section{Introduction}

Migration of population has been a recurrent phenomenon since the dawn of human civilization. Migration refers to a process of "spatial separation between the location of a resident household or family and one or more livelihood activities engaged by family members" (Ellis and Freeman, 2006). Migration is the movement of people from one geographical location to another, involving permanent or temporary settlement. The region where people are leaving is referred to as the source region whereas the region to which people are entering is known as destination region.

Analysis of migration pattern is important to understand the changes taking place in the People's movement within the country. It is most volatile component of population growth and most sensitive to economic, political and 
cultural factors (Singh, 1998). Analysis of the pattern of migration helps us to assess the role of various social and economic factors influencing migration. The characteristics of migration can be studied in two ways one by distance covered in the migration and the other by the streams of migration. On the basis of administrative boundaries crossed and not crossed, internal migration is classified as intra-district, inter-district and inter-state. This is roughly indicative of distance of migration.

In Karnataka with respect to farming system there are lot of disparities between North and South and the drought is more prevalent in North which has lead to the migration of agriculture labourers, small and marginal farmers from north to south Karnataka in search of jobs. The poor, small and marginal farm households have to search for alternative sources of livelihood during the slack season in agriculture. Further the small size of land holding also does not help generate employment on a large scale. Hence one or two members of the household move out in search of employment. Hence migration seems to be a common phenomenon. With this background, the study was undertaken with the following objectives,

To study the socio-economic status of migrants

To identify the existing migration pattern among the migrants and to find out the factors responsible for migration

\section{Materials and Methods}

The study was conducted in Yadagir district of Karnataka during the year 2014-15. The district was purposively selected because of convenience and familiarity of the researcher with the study area and because of the stark contrast between the rainfed dry areas and the irrigated area existing in the district. The Ex- post-facto-research design was used for the study. This design was considered appropriate because the phenomenon has already occurred. Yadagir district comprises of three taluks viz., Yadagir, Shahapur and Shorapur. All the three taluks were selected and from each taluk 5 villages were selected. Thus a total of 15 villages were selected for the study. From each of the selected village 10 farmers and 10 agricultural labourers were selected randomly for the study thus making a total sample of 300 respondents. The data was collected personally from the respondents using structured and standardized interview schedule developed for the study. The data collected was tabulated and analyzed using appropriate statistical tools.

\section{Results and Discussion}

\section{Personal, socio-economic status of the migrant farm family members}

It was revealed from pooled data of Table 1 that, less than half $(40.00 \%)$ of the respondents were middle aged followed by young aged $(38.33 \%)$ and old aged group $(21.67 \%)$. With respect to education, half $(50.00 \%)$ of the respondents were illiterates and one fourth $(25.00 \%)$ of them were educated up to primary school. Very meager percent of them were educated upto Pre University (3.33\%) and degree level (2.67\%).

With regard to land holding, it was clear from the pooled data that, equal per cent $(28.33 \%)$ of the respondents were having a land holding of 1.1-2acre and 2.1-3 acres. One fifth (20.00 $\%$ ) of them were having a land holding of 3.14 acres.

In case of farming experience, majority (46.00 $\%$ ) of the respondents belonged to medium farming experience category followed by low $(28.00 \%)$ and high $(26.00 \%)$ categories respectively. 
Table.1 Distribution of respondents based on their socio-economic characteristics

\begin{tabular}{|c|c|c|c|c|c|c|c|c|}
\hline \multirow[t]{2}{*}{$\begin{array}{l}\text { Sl. } \\
\text { No. }\end{array}$} & \multirow{2}{*}{\multicolumn{2}{|c|}{ Category }} & \multicolumn{2}{|c|}{$\begin{array}{c}\text { Farmers } \\
\left(\mathbf{n}_{1}=150\right)\end{array}$} & \multicolumn{2}{|c|}{$\begin{array}{l}\text { Agricultural } \\
\text { Laborers } \\
\left(\mathbf{n}_{\mathbf{2}}=\mathbf{1 5 0}\right)\end{array}$} & \multicolumn{2}{|c|}{ Pooled } \\
\hline & & & $\mathbf{F}$ & $\%$ & $\mathbf{F}$ & $\%$ & $\mathbf{F}$ & $\%$ \\
\hline \multirow[t]{4}{*}{ I } & \multicolumn{2}{|c|}{ Age } & & & & & & \\
\hline & 1. & Young $(<30)$ & 65 & 43.33 & 48 & 32.00 & 115 & 38.33 \\
\hline & 2. & Middle (31 to 49) & 51 & 34.00 & 65 & 43.33 & 120 & 40.00 \\
\hline & 3. & Old $(>50)$ & 34 & 22.67 & 37 & 24.67 & 65 & 21.67 \\
\hline \multirow[t]{7}{*}{ II } & \multicolumn{8}{|c|}{ Education } \\
\hline & 1. & Illiterate & 78 & 52 & 72 & 48.00 & 150 & 50.00 \\
\hline & 2. & Primary & 37 & 24.67 & 37 & 24.67 & 75 & 25.00 \\
\hline & 3. & Middle school & 20 & 13.33 & 25 & 16.67 & 45 & 15.00 \\
\hline & 4. & High school & 5 & 3.33 & 7 & 4.67 & 12 & 4.00 \\
\hline & 5. & Pre-university & 5 & 3.33 & 6 & 4.00 & 10 & 3.33 \\
\hline & & Degree and above & 5 & 3.33 & 3 & 2.00 & 8 & 2.67 \\
\hline \multirow[t]{6}{*}{ III } & \multicolumn{8}{|c|}{ Land holding } \\
\hline & 1. & $<1$ acre & 0 & 0.00 & 45 & 30.00 & 45 & 15.00 \\
\hline & 2. & 1.1-2acre & 0 & 0.00 & 75 & 50.00 & 85 & 28.33 \\
\hline & 3. & 2.1-3 acre & 55 & 36.67 & 30 & 20.00 & 85 & 28.33 \\
\hline & 4. & 3.1-4 acre & 60 & 40.00 & 0 & 0.00 & 60 & 20.00 \\
\hline & & 4.1-5 acre & 35 & 23.33 & 0 & 0.00 & 25 & 8.33 \\
\hline \multirow[t]{4}{*}{ VI } & \multicolumn{8}{|c|}{ Farming experience } \\
\hline & 1. & Low (mean-0.425*SD) & 39 & 26.00 & 45 & 30.00 & 84 & 28.00 \\
\hline & 2. & Medium(Mean $\left.\pm 0.425^{*} \mathrm{SD}\right)$ & 63 & 42.00 & 75 & 50.00 & 138 & 46.00 \\
\hline & 3. & High $($ mean $+0.425 * S D)$ & 48 & 32.00 & 30 & 20.00 & 78 & 26.00 \\
\hline \multirow[t]{3}{*}{$\mathbf{V}$} & \multicolumn{8}{|c|}{ Family size } \\
\hline & 1. & Up to 4 members & 35 & 23.33 & 48 & 32.00 & 79 & 26.33 \\
\hline & & More than 4 members & 115 & 76.67 & 102 & 68.00 & 221 & 73.67 \\
\hline \multirow[t]{3}{*}{ VI } & \multicolumn{8}{|c|}{ Gender } \\
\hline & 1. & Male & 108 & 72 & 101 & 67.33 & 208 & 69.33 \\
\hline & & Female & 42 & 28 & 49 & 32.67 & 92 & 30.67 \\
\hline VII & \multicolumn{8}{|c|}{ Annual income } \\
\hline & 1. & Low (mean- $0.425^{*} \mathrm{SD}$ ) & 45 & 30.00 & 35 & 23.33 & 80 & 26.67 \\
\hline & 2. & Medium $($ Mean $\pm 0.425 * \mathrm{SD})$ & 58 & 38.67 & 60 & 40.00 & 117 & 39.00 \\
\hline & 3. & High $\left(\right.$ mean $\left.+0.425^{*} \mathrm{SD}\right)$ & 47 & 31.33 & 55 & 36.67 & 103 & 34.33 \\
\hline
\end{tabular}


Table.2 Migration pattern among farmers and agricultural laborers

\begin{tabular}{|c|c|c|c|c|c|c|c|}
\hline \multirow[t]{2}{*}{$\begin{array}{l}\text { Sl. } \\
\text { No. }\end{array}$} & \multirow[t]{2}{*}{ Category } & \multicolumn{2}{|c|}{$\begin{array}{c}\text { Farmers } \\
\left(\mathbf{n}_{1}=150\right)\end{array}$} & \multicolumn{2}{|c|}{ Agril. Laborers $\left(\mathbf{n}_{2}=150\right)$} & \multicolumn{2}{|c|}{ Pooled } \\
\hline & & $\mathbf{F}$ & $\%$ & $\mathbf{F}$ & $\%$ & $\mathbf{F}$ & $\%$ \\
\hline \multirow[t]{4}{*}{ I. } & \multicolumn{7}{|l|}{ Based on distance } \\
\hline & Intra district & 40 & 13.33 & 38 & 12.67 & 77 & 25.67 \\
\hline & Inter district & 103 & 34.33 & 95 & 31.67 & 198 & 66.00 \\
\hline & Inter state & 7 & 2.33 & 17 & 5.67 & 25 & 8.33 \\
\hline \multirow[t]{3}{*}{ II. } & \multicolumn{7}{|l|}{ Based on streams } \\
\hline & Rural to urban & 118 & 78.67 & 135 & 90.00 & 252 & 84.00 \\
\hline & Rural to rural & 32 & 21.33 & 15 & 10.00 & 48 & 16.00 \\
\hline \multirow[t]{4}{*}{ III. } & Based on time & & & & & & \\
\hline & Temporary migration & 35 & 23.33 & 21 & 14.00 & 56 & 18.67 \\
\hline & Permanent migration & 13 & 8.67 & 18 & 12.00 & 25 & 8.33 \\
\hline & Seasonal migration & 102 & 68.00 & 111 & 74.00 & 219 & 73.00 \\
\hline
\end{tabular}

*F= Frequency, \%= Percentage

Table.3 Distribution of respondents based on factors of migration (inward migration)

\begin{tabular}{|c|c|c|c|c|c|c|c|}
\hline \multirow[t]{2}{*}{$\begin{array}{l}\text { Sl. } \\
\text { No. }\end{array}$} & \multirow[t]{2}{*}{ Factors } & \multicolumn{2}{|c|}{$\begin{array}{c}\text { Farmers } \\
\left(n_{1}=150\right)\end{array}$} & \multicolumn{2}{|c|}{$\begin{array}{c}\text { Agril. } \\
\text { Laborers } \\
\left(\mathrm{n}_{2}=150\right)\end{array}$} & \multicolumn{2}{|c|}{ Pooled } \\
\hline & & $\mathbf{F}$ & $\%$ & $\mathbf{F}$ & $\%$ & $\mathbf{F}$ & $\%$ \\
\hline 1. & Unemployment & 148 & 98.67 & 140 & 93.33 & 288 & 96.00 \\
\hline 2. & Offseason & 140 & 93.33 & 148 & 98.67 & 288 & 96.00 \\
\hline 3. & Lack of irrigation facility & 127 & 84.67 & 123 & 82.00 & 250 & 83.33 \\
\hline 4. & Due to debt & 90 & 60.00 & 120 & 80.00 & 210 & 70.00 \\
\hline 5. & Low agricultural productivity & 28 & 18.67 & 15 & 10.00 & 43 & 14.33 \\
\hline 6. & Failure of crop due to pest and diseases & 15 & 10.00 & 20 & 13.33 & 35 & 11.67 \\
\hline 7. & Low wage rate & 145 & 96.67 & 135 & 90.00 & 280 & 93.33 \\
\hline 8. & Lack of timely availability of quality inputs & 28 & 18.67 & 15 & 10.00 & 43 & 14.33 \\
\hline 9. & Limited livelihood options in rain fed areas & 83 & 55.33 & 120 & 80.00 & 203 & 67.67 \\
\hline 10. & Improvement in transport facilities & 78 & 52.00 & 100 & 66.67 & 178 & 59.33 \\
\hline 11. & $\begin{array}{l}\text { Unpleasant relations with neighbor and } \\
\text { family }\end{array}$ & 5 & 3.33 & 7 & 4.67 & 12 & 4.00 \\
\hline 12. & Poor economic condition of the family & 145 & 96.67 & 148 & 98.67 & 293 & 97.67 \\
\hline 13. & Large family size & 118 & 78.67 & 108 & 72.00 & 226 & 75.33 \\
\hline 14. & Marriage & 43 & 28.67 & 55 & 36.67 & 98 & 32.67 \\
\hline 15. & Lack of credit facilities & 58 & 38.67 & 100 & 66.67 & 158 & 52.67 \\
\hline 16. & Fragmentation in land holding & 15 & 10.00 & 0 & 0.00 & 15 & 5.00 \\
\hline
\end{tabular}


Table.4 Distribution of respondents based on purpose of migration (outward factors)

\begin{tabular}{|c|c|c|c|c|c|c|c|}
\hline \multirow[t]{2}{*}{$\begin{array}{l}\text { Sl. } \\
\text { No. }\end{array}$} & \multirow[t]{2}{*}{ Purpose } & \multicolumn{2}{|c|}{$\begin{array}{l}\text { Farmers } \\
\left(\mathbf{n}_{1}=150\right)\end{array}$} & \multicolumn{2}{|c|}{$\begin{array}{l}\text { Agril. Laborers } \\
\left(\mathbf{n}_{2}=\mathbf{1 5 0}\right)\end{array}$} & \multicolumn{2}{|c|}{ Pooled } \\
\hline & & $\mathbf{F}$ & $\%$ & $\mathbf{F}$ & $\%$ & $\mathbf{F}$ & $\%$ \\
\hline 1. & To get employment & 147 & 98.00 & 140 & 93.33 & 287 & 95.67 \\
\hline 2. & To do business & 3 & 2.00 & 10 & 6.67 & 13 & 4.33 \\
\hline 3. & To obtain better standard of living & 137 & 91.33 & 135 & 90.00 & 272 & 90.67 \\
\hline 4. & To get better amenities & 135 & 90.00 & 145 & 96.67 & 280 & 93.33 \\
\hline 5. & To get gender equality & 25 & 16.67 & 40 & 26.67 & 65 & 21.67 \\
\hline 6. & $\begin{array}{l}\text { To obtain improvement in } \\
\text { children education }\end{array}$ & 30 & 20.00 & 25 & 16.67 & 55 & 18.33 \\
\hline 7. & To get regular income & 147 & 98.00 & 143 & 95.33 & 290 & 96.67 \\
\hline 8. & To get marriage security & 43 & 28.67 & 55 & 36.67 & 98 & 32.67 \\
\hline 9. & Due to wage differentials & 143 & 95.33 & 145 & 96.67 & 288 & 96.00 \\
\hline 10. & Due to Irrigation facilities & 30 & 20.00 & 25 & 16.67 & 55 & 18.33 \\
\hline
\end{tabular}

$* \mathrm{~F}=$ Frequency, $\%=$ Percentage

*Multiple responses may occur

With respect to family size and gender, it was clear from the pooled data that majority $(73.67 \%)$ of the respondents was having a family size of more than 4 members and majority $(69.33 \%)$ of the respondents was male.

In case of annual income, little less than forty $(39.00 \%)$ per cent of the respondents belonged to medium annual income category followed by high $(34.33 \%)$ and low (26.67 $\%$ ) income categories respectively.

\section{Migration pattern among farmers and agricultural laborers}

It was observed from Table 2 that, more than half $(66.00 \%)$ of the respondents were interdistrict migrants, followed by intra-district $(25.67 \%)$ and inter-state $(8.33 \%)$ migrants. The reason for high percentage of interdistrict migration might be due to urbanization, industrialization, better employment opportunities and transportation facilities available in the nearby districts. At the same time lower inter-state migration might be due to long distance from the place of origin and language. The above results are in conformity with the research findings obtained by Premi (1990).

The pooled data presented in Table 2 revealed that, majority $(84.16 \%)$ of the farm families were fall under rural to urban migration. Whereas lower per cent $(15.83 \%)$ of the farm families were rural to rural migrants. The probable reasons for high per cent of rural to urban migration might be due to availability of job opportunities in urban areas because of industrialization and availability of better facilities in the urban areas compared to rural areas. The above result was in conformity with the results of Siddiq (2004) and Aweormi (2011).

It was observed from Table 2 that, majority $(73.00 \%)$ of the respondents were seasonal migrants and 18.67 and 8.33 per cent of them were Temporary and permanent migrants respectively. This might be attributed to the fact that, unemployment during agriculture lean season and often may be linked to debt cycles and the need of money for repaying debts, covering deficits created by losses 
covered in agriculture and festivals, poor economic condition of the family which enforces them to move out in search of employment. The results are in conformity with results obtained by Deshingkar (2008) and Uma et al., (2014).

\section{Purpose and factors of migration influencing the farm families}

\section{Factors of migration (inward migration)}

It was revealed from the pooled data presented in Table 3 that, large majority $(97.67 \%)$ of the respondents migrated due to poor economic condition of the family, followed by unemployment and offseason or agriculture lean season (96.00\%), due to low wage rate $(93.33 \%)$ and due to lack of irrigation facility $(83.33 \%)$.

The possible reason could be that the farmers or the migrants posses small land holding that to in rainfed condition with large family size and in rainfed situation one to two crop are taken and in offseason there is no work and a low wage existed in the rainfed area compared to the irrigated area.

Another factor responsible for the migration was large family size $(75.33 \%)$ of respondents followed by debt $(70.00 \%)$, limited livelihood options in rainfed areas $(67.67 \%)$ per cent, improvement in transport facilities $(59.33 \%)$ and lack of credit facilities $(52.67 \%)$. The study was conducted in dry land area which is a major reason for migration, hence the above mentioned were the factors which in particular influenced the farmers to migrate, the probable reason may be lack of financial support employment opportunities in the study area, lack of basic amenities like medical facilities, schooling, transportation, entertainment and other possible reason could be constant debt and no opportunity to repay it back.
A very less per cent $(5.00 \%)$ gave the reason of fragmentation of land holding and unpleasant relationship with neighbour and family $(4.00 \%)$ as a factor to migrate. In study it is observed that the majority of farmers are from big family size it is known fact that in village all live in harmony but very few villagers maintain the unpleasant relation with labour and family. The results are in conformity with the research findings of Kumar (2014) and Khosla (2010).

\section{Purpose of migration}

It was observed from pooled data in Table 4 that, large majority (96.67 \%) of the respondents purpose of migration was to get regular income, followed by due to wage differentials $(96.00 \%)$, to get employment (95.67\%), to get better amenities $(93.33 \%)$ and to obtain better standard of living (90.67 $\%)$. This might be attributed to the fact that, non-availability of regular income in the place of domicile, unemployment and less job opportunities throughout the year, due to lower wage rate in the place of origin, lack of basic facilities and low standard of living due to less annual income are the major purpose of migration.

Less percent of farmers' purpose of migration was to get marriage security, to get gender equality, due to irrigation facility, to obtain improvement in children education.

It was observed that farmers migrate from dryland area to irrigated area to earn more and few farmers migrate from village to district places to provide better education for their children, very meager $(4.33 \%)$ of the farmers migrated to do business as it is known that, to do business, business skill and finance are required so very few are migrated who are financially fit to do the business. The results are in line with the findings of Mohapatra (2011). 
It can be concluded from the results of the study that, motivational factor for majority of the migrants was poor economic condition of the family and unemployment. The main purpose for majority of farmers' migration was to get higher income. Further, majority of farmers' purpose of migration was employment opportunity. The major portion of the migrants belongs to young and middle age group. There is a need to develop village level plans for proper utilization of resources, man power in each village for proper engagement of the farmers in villages during lean season. The farmers who had good educational background can be motivated and trained to start agro industries with financial support from nationalized banks to reduce the migration from rural to urban.

\section{References}

Aworemi, 2011. An appraisal of the factors influencing rural-urban migration in some selected local government areas of Lagos state Nigeria. pp. 8-14.

Deshingkar, P., 2008. Circular internal migration and development migration and development within and across borders: Research and policy perspectives on internal and international migration.
Ellis and Ade Freeman, H., 2006. Conceptual framework and overview of theme in Frank Ellis and Ade Freeman, $\mathrm{H}$ [eds.], Rural Livelihood and Poverty Reduction Policies. New York: Routledge. pp. 316

Khosla, R., 2010. The new economic \& climatic context and changing migration pattern in India, Final report, 10: 108-117.

Kumar, A., 2014. Impact of rural migration on agricultural labourers of Bihar in Assam (A case study of Cachar district), Kurukshetra, 62(11): 29-31.

Mohapatra, R. S., 2011. The changing pattern of internal migration in India issues and challenges. pp. 1-15.

Premi, M. K., 1990. Internal handbook on internal migration, Greenwood Press, 30(1): 49-59.

Singh, D. P., 1998. Internal migration in India: 1961-1991. Demography India, 27(1): 245-61.

Uma, H. R., Madhu, G. R., Muhammad, H., 2013. An analysis of the causes of regional migration using Garrett's scale. Univ. Mys. IOSR, J. Humanities and Soc. Sci., (IOSR-JHSS) 12(1): 20-23.

\section{How to cite this article:}

Moulasab, D.M. Chandargi and Sathihal, D.G. 2018. Migration Trend Analysis of Farmers and Agricultural Labours in Yadgir District of Karnataka, India. Int.J.Curr.Microbiol.App.Sci. 7(01): 3126-3132. doi: https://doi.org/10.20546/ijcmas.2018.701.371 